\title{
REVIEW
}

\section{Oral cancer: changing the aim of the biopsy in the age of precision medicine. A review}

\author{
Il cancro del cavo orale: ridefinizione del ruolo delle biopsie nell'era della medicina \\ di precisione. Review della letteratura \\ Roberto Bruschini ${ }^{1}$, Fausto Maffini², Fausto Chiesa1, Daniela Lepanto², Rita De Berardinis ${ }^{1}$, Francesco Chu', \\ Marta Tagliabue ${ }^{1}$, Gioacchino Giugliano ${ }^{1}$, Mohssen Ansarin ${ }^{1}$ \\ ${ }^{1}$ Division of Otolaryngology and Head \& Neck Surgery, European Institute of Oncology IRCCS, Milan, Italy; ${ }^{2}$ Division of Pathology, \\ European Institute of Oncology IRCCS, Milan, Italy
}

\begin{abstract}
SUMMARY
Oral cancer is a heterogeneous disease that develops through a complex, multi-step process. Precision medicine should help to better understand its molecular basis, integrate traditional classifications and have a positive impact on cancer management. To apply this information in clinical practice, we need to define its histology and identify biomarkers expressed by the tumour that provide useful information for planning tailored treatment. The most reliable information currently derives from evaluation of biomarkers on post-operative samples. To plan personalised treatment, oncologists need to assess these markers on biopsy samples. We reviewed the recent literature and identified 6 of 184 publications that compared markers measured on biopsy and post-operative samples or assessed their predictivity for the development of lymph node metastases. Data from these studies suggest that markers measured on biopsy samples can provide useful indications for tailoring treatments. However, due to their heterogeneity and low level of evidence, these results need to be confirmed by clinical studies on a large population to standardise and validate biomarkers in biopsies and to assess their reliability in other diagnostic mini-invasive procedures such as radiomics and liquid biopsy.
\end{abstract}

KEY WORDS: surgical biopsy, liquid biopsy, radiomics, depth of invasion, precision medicine

\section{RIASSUNTO}

Il cancro orale è una malattia eterogenea che origina ed evolve con un processo complesso e multifasico. La medicina di precisione permette di pianificare un trattamento personalizzato sulla base delle caratteristiche biologiche e molecolari delle singole neoplasie. Le informazioni oggi più affidabili sono fornite dalla valutazione post-operatoria dei biomarcatori, ma per pianificare un trattamento personalizzato è necessario valutare questi marcatori sulla biopsia. Per questo abbiamo rivisto la letteratura dell'ultimo quinquennio ed abbiamo identificato $6 / 184$ articoli che valutano i marcatori sulla biopsia confrontandone $i$ valori con quelli misurati sul pezzo operatorio di ciascun paziente o valutandone la predittività per lo sviluppo di metastasi linfonodali. I dati che emergono da questi studi suggeriscono che la valutazione dei marcatori sul campione bioptico potrebbe fornire indicazioni utili per programmare trattamenti personalizzati. Tuttavia, a causa della eterogeneità e del basso livello di evidenza dei lavori considerati, questi risultati devono essere confermati da studi clinici su un'ampia popolazione per standardizzare e validare i biomarcatori e la loro affidabilità in altre procedure mini-invasive, ad esempio radiomica e biopsia liquida.

PAROLE CHIAVE: biopsia chirurgica, biopsia liquida, radiomica, profondità di invasione, medicina di precisione

\section{Introduction}

Cancer of the oral cavity is the eighth most common cancer worldwide: GLOBOCAN reported an estimated 354,900 new cases in 2018; about $90 \%$ of these tumours are oral squamous cell carcinomas (OSCCs) with a 5-year survival of
Received: August 11, 2020

Accepted: February 3, 2021

Correspondence

Francesco Chu

Division of Otolaryngology and Head \& Neck Surgery

European Institute of Oncology

via Ripamonti 435, 20141 Milano, Italy

E-mail: Francesco.Chu@ieo.it

Funding

None.

Conflict of interest

The Authors declare no conflict of interest.

How to cite this article: Bruschini R, Maffini F, Chiesa F, et al. Oral cancer: changing the aim of the biopsy in the age of precision medicine. A review. Acta Otorhinolaryngol Ital 2021;41:108119. https://doi.org/10.14639/0392-100X-N1056

(C) Società Italiana di Otorinolaringoiatria e Chirurgia Cervico-Facciale

\section{(c) (1) $(9)$}

This is an open access article distributed in accordance with the CC-BY-NC-ND (Creative Commons Attribution-NonCommercial-NoDerivatives 4.0 International) license. The article can be used by giving appropriate credit and mentioning the license, but only for non-commercial purposes and only in the original version. For further information: https:// creativecommons.org/licenses/by-nc-nd/4.0/deed.en 
$<60 \%{ }^{1}$ OSCCs can arise from the oral tongue, which is the most common sub-site and has the worse prognosis ${ }^{2-4}$, followed by the floor of mouth, buccal mucosa, alveolar mucosa, and hard palate. Historically, OSCC affects older people, mainly men, smokers and alcohol drinkers. Recent clinical and epidemiological studies have reported an overall decline in the incidence of tobacco-related OSCCs, probably due to the anti-smoking campaigns ${ }^{5-7}$, but an increasing trend of tongue and oropharyngeal cancers in younger patients, women and individuals with no exposure to traditional risk factors ${ }^{8-10}$. While infection with human papillomavirus accounts for an increasing number of patients with oropharyngeal cancers, risk factors, especially viruses, in OSCC nonsmokers and non-drinkers, are unclear ${ }^{11,12}$. Head and neck cancer (HNC), including OSCC, is a heterogeneous disease that develops through a complex, multi-step process involving genetic alterations, growth regulation, apoptosis, angiogenesis, invasion and metastasis; moreover, it is influenced by the individual's genetic predisposition and environmental exposure to carcinogens ${ }^{13,14}$. This heterogeneity is confirmed in daily practice by the observation that patients with clinically similar tumours have different treatment responses and outcomes ${ }^{15,16}$.

\section{Precision medicine}

To address this heterogeneity, the Cancer Genome Atlas project ${ }^{17}$, classifications based on molecular pathology ${ }^{18}$, and the Precision Medicine Initiative ${ }^{19}$ have been proposed. These efforts should help to better understand the molecular basis of cancer, integrate traditional classifications and have a positive impact on cancer management ${ }^{20}$. Given this complexity, both the diagnosis and therapy of OSCCs should be planned by a highly specialised multidisciplinary team that is able to globally assess the disease and patient ${ }^{21,22}$. Such personalised diagnostic and treatment strategies which precisely target molecular alterations refer to Precision Medicine or Genomics-Driven Cancer Medicine ${ }^{23-25}$. To apply precision medicine in clinical practice, we need to identify biomarkers expressed by tumours that reflect their individual characteristics ${ }^{26-28}$.

Tissue biomarkers validated on post-operative surgical specimens

Many prognostic/predictive biomarkers have been taken into account and tested, such as c-erbB2, EGFR (Epidermal Growth Factor Receptor), tumour infiltrating lymphocytes, c-met, etc., and currently the most reliable information on high-risk patients derives from assessment of tissue biomarkers on post-operative samples. In 2004, two trials by the European Organization for Research and Treatment of Cancer (EORTC), and the United States Ra- diation Therapy Oncology Group (RTOG) compared adjuvant radiation alone $v s$ chemoradiation in advanced head and neck cancers. The results showed that the addition of concurrent chemotherapy was associated with better oncologic outcomes compared to radiation alone in a subset of high risk patients. They evaluated pathological classification of the primary tumour, positive margins, tumour depth, positive nodes, extranodal extension (ENE), lympho-vascular invasion (LVI), perineural invasion (PNI) and histology grade ${ }^{29,30}$. A subsequent comparative analysis of data pooled from these two trials showed that ENE and/or microscopically involved surgical margins were the only risk factors for which the impact of post-operative chemoradiotherapy was significant in both trials ${ }^{31}$. Cooper et al. in 2012 confirmed these data by evaluating the long-term results of patients enrolled in the RTOG study. They found that at 10 years, local recurrence and disease-free survival rates were significantly better only in patients included in the chemo-radiotherapy arm for ENE and/or microscopically involved margins ${ }^{32}$. Subsequently, other studies confirmed these data and proposed risk classes for effective post-operative therapeutic planning ${ }^{33-36}$. The $8^{\text {th }}$ edition of the TNM staging system ${ }^{20}$ suggests that HPV and depth of invasion (DOI) as well as specific biomarkers expressed by HNCs should be assessed. OSCCs are rarely related to HPV, while DOI is useful to evaluate biological behaviour, because prognosis worsens when the tumour is deeper ${ }^{37,38}$. In the past, the DOI of early-stage tongue tumours (T1T2) was considered a predictor of occult lymph node metastases, as in skin carcinomas, and was used to plan neck dissection ${ }^{39,40}$. Before the publication of the TNM, 8th Edition, the terms "Tumour Thickness (TT)" and "Depth of Invasion (DOI)" were often considered synonymous. However, DOI, as defined in the AJCC (American Joint Committee on Cancer) Cancer Staging Manual $8^{\text {th }}$ Edition, has a better predictive value than TT ${ }^{38,41}$. Recent studies based on this definition suggest that DOI $>4 \mathrm{~mm}$ (range: $3.4 \mathrm{~mm}-6.6 \mathrm{~mm}$ ) is a strong predictor of locoregional recurrence, and survival together with two or more markers such as PNI, LVI and Worst Pattern Of Invasion (WPOI-5) ${ }^{42-44}$ which have been integrated into the 8th TNM edition. In addition, several studies have highlighted tumour budding (BD) and tumour-stroma ratio (TSR), considered in other non-TNM-based staging systems, as predictive factors for lymphatic diffusion and disease-free survival (DFS) ${ }^{15,45-47}$. Table I shows the definition and purpose of these markers $2,15,37,38,42,45,46,48-57$.

To plan personalised treatment, oncologists need to assess these markers, including DOI, on biopsy samples according to the AJCC TNM (8th edition) recommendations ${ }^{38}$. Herein, we review the literature in order to evaluate the 
Table I. Pathological markers predictive of loco-regional recurrence and prognosticators.

\begin{tabular}{|c|c|c|}
\hline Marker & Definition & Notes \\
\hline Depth of Invasion (DOI) & $\begin{array}{l}\text { DOI is measured from the level of the basement } \\
\text { membrane of the closest adjacent normal } \\
\text { mucosa. A "plumb line" is dropped from this plane } \\
\text { to the deepest point of tumour invasion }{ }^{38,42}\end{array}$ & $\begin{array}{l}\text { Included in T1-3 Categories for Oral Cavity Cancer, TNM Staging } \\
\text { Manual 8th Edition }{ }^{37} \\
\text { The T category increases with every interval of } 5 \mathrm{~mm}\end{array}$ \\
\hline Tumour Thickness (TT) & $\begin{array}{l}\text { TT is measured from the surface of the tumour } \\
\text { to the deepest point of invasion. In exofitic and } \\
\text { ulcerated lesions TT is measured from the } \\
\text { imaginary line reconstructing the intact mucosa to } \\
\text { the deepest point of invasion }{ }^{42,48} \\
\text { TT1 is measured from the level of adjacent } \\
\text { mucosa to the deepest point of tumour invasion }{ }^{49} \\
\text { TT2 is the distance from the bottom of most } \\
\text { adjacent dysplastic abnormal rete pegs to the } \\
\text { deepest point of invasion }{ }^{49} \\
\text { TT3 is measured as distance from the epithelial } \\
\text { junction of the most adjacent dermal papillae to } \\
\text { the deepest point of tumour invasion }{ }^{49}\end{array}$ & $\begin{array}{l}\text { As defined before publication of the } 8^{\text {th }} \text { TNM Edition }{ }^{42,48} \text { or defined as } \\
\text { an alternative to the proposed classification }{ }^{49} \\
\text { Rete pegs: epithelial extensions in the connective tissue underlying } \\
\text { the mucosa }{ }^{49}\end{array}$ \\
\hline $\begin{array}{l}\text { Radiological Depth of Invasion } \\
\text { (rDOI) }\end{array}$ & $\begin{array}{l}\text { rDOI is measured by drawing a perpendicular line } \\
\text { from the reference line to the deepest point of } \\
\text { the tumour } 50\end{array}$ & $\begin{array}{l}\text { Radiological definition of DOI is also reported in TNM } 8^{\text {th }} \text { Edition }{ }^{37 .} \text {. The } \\
\text { reference line connects the junction of the tumour surfaces and of } \\
\text { the normal mucosa on both sides }{ }^{50}\end{array}$ \\
\hline Tumour Budding (TB) & $\begin{array}{l}\text { TB is defined as the presence of either isolated } \\
\text { single cells or small-cell clusters comprising fewer } \\
\text { than five cells scattered in the stroma ahead of } \\
\text { the invasive tumour front } 15,45,48,51-54\end{array}$ & $\begin{array}{l}\text { TB is speculated to be the result of interactions between cancer cells } \\
\text { and tumour microenvironments. It is expression of loss of cohesion } \\
\text { and active invasive cellular movement }{ }^{55} \text {. It is considered the first step } \\
\text { in metastasis of a solid tumour }\end{array}$ \\
\hline Pattern of Invasion (POI) & $\begin{array}{l}\text { POI at the tumour-host interface of oral cancer is } \\
\text { graded } 1 \text { to } 5 .\end{array}$ & \multirow{2}{*}{$\begin{array}{l}\text { Tumour dispersion is assessed at the advancing tumour edge. } \\
\text { The most common WPOI-5 phenotype is tumor dispersion } \\
\text { through soft tissue. Dispersed extratumoral peri-neural invasion, } \\
\text { or extratumoral lymphovascular invasion, also can qualify for } \\
\text { classification as WPOI-5 }{ }^{37}\end{array}$} \\
\hline Worst Pattern of Invasion (WPOI) & $\begin{array}{l}\text { WPOI-5 (POI Grade 5) consists of dispersed, } \\
\text { discontinuous growth pattern, with a defined } \\
\text { tumour dispersion cutoff of } 1 \mathrm{~mm}^{37,54}\end{array}$ & \\
\hline Tumour-Stroma Ratio (TSR) & $\begin{array}{l}\text { TSR defines the interactions between cancer cells } \\
\text { and intra-tumoural stroma, which is the main } \\
\text { component of the microenvironment } 46,56,57\end{array}$ & $\begin{array}{l}\text { These interactions are important for both cancer initiation and progression: } \\
\text { the proportion of this stroma acts as a key regulator in cancer biology and } \\
\text { could provide strategies for biological cancer treatment }\end{array}$ \\
\hline Peri Neural Invasion (PNI) & $\begin{array}{l}\text { PNI is defined as the tumour cell infiltration in } \\
\text { any layer of the nerve sheath or tumour in close } \\
\text { proximity involving more than one-third of the } \\
\text { nerve circumference } 49\end{array}$ & $\begin{array}{l}\text { PNI should be subclassified as either intratumoral or extratumoral, } \\
\text { and as focal or multifocal. Extensive multifocal PNI is usually } \\
\text { extratumoral and frequently associated with a "strand-like" tumour } \\
\text { phenotype }{ }^{37}\end{array}$ \\
\hline Lympho Vascular Invasion (LVI) & $\begin{array}{l}\text { LIV is defined as the detection of tumour epithelial } \\
\text { cells within or attached to the endothelial cell } \\
\text { lining of the vascular space }{ }^{49}\end{array}$ & $\begin{array}{l}\text { LIV should be reported as either intratumoral or extratumoral, as well } \\
\text { as focal or multifocal }{ }^{37}\end{array}$ \\
\hline
\end{tabular}

concordance between the values of tissue biomarkers measured in both pre-operative and post-operative samples from the same patient.

\section{Methods}

For this purpose, we reviewed the recent literature published in English (January 2015-December 2019) by consulting the PubMed, Medline, Web of Science, Embase and Cochrane databases. We used the following keywords (strings): oral biopsy and depth of infiltration/DOI; oral biopsy and tumour/tumor budding; oral cancer diagnosis and depth of infiltration/DOI; oral cancer diagnosis and tumour/tumor budding. Only peer-reviewed papers were considered. We thus identified 184 papers (Fig. 1); 90 of these were duplicates. The remaining 94 were evaluated based on the abstracts. Inclusion criteria were: A) histologically proven squamous cell carcinomas (SCC) of the oral cavity; B) both prospective and retrospective studies; C) papers that compared biopsy and post-operative samples from the same patient; D) papers that evaluated predictivity of biomarkers on biopsy specimens; E) articles based on a retrospective series whose biopsy and postoperative slides were reviewed by the authors. Exclusion criteria: a) reviews, case reports, abstracts; b) histology other than SCC; c) studies that did not review histologi- 


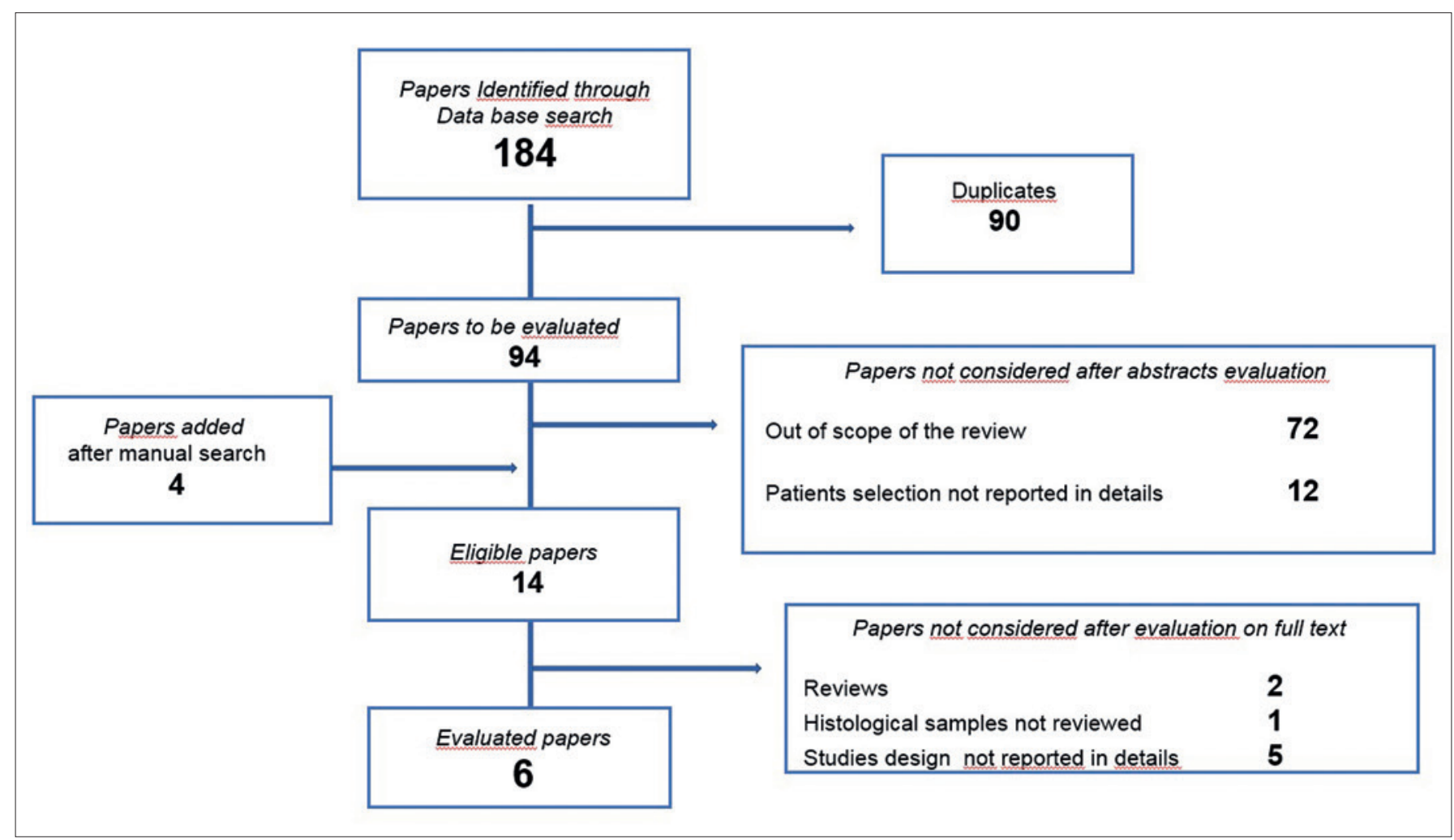

Figure 1. Flow chart showing selection of papers.

cal samples. As a result of this analysis, we discarded 72 papers unrelated to our aim; for 12 studies, criteria for patient selection or study design were not reported in detail. Fourteen papers (the 10 selected articles and 4 others identified through a manual search) were evaluated on the complete text. Following this analysis, 8 more papers were considered unsuitable for our purpose as they were reviews or the study design did not fall within the selection criteria.

\section{Results}

All six papers included were retrospective, and were divided into two groups based on the aim of the study (Tab. II) ${ }^{48,49,58-61}$ :

Comparison of tissue markers on biopsy and post-operative samples. Three papers ${ }^{58-60}$ compared the values of biomarkers measured on patient's biopsy and post-operative samples from the same patients in order to evaluate their concordance and reliability. Almangush et al. ${ }^{58}$ reviewed the slides of 100 patients $(81=$ Stage I-II) with SCC of the mobile tongue treated with surgical excision. They measured TT and found that mean values were 4.1 $\mathrm{mm}(0.5-10 \mathrm{~mm})$ in biopsy samples vs $6.3 \mathrm{~mm}(0.5-23$ $\mathrm{mm}$ ) in the corresponding post-operative specimens. They also evaluated TB (Tab. I) and their prognostic score (BD Model, Tab. III), and documented a sensitivity and specificity of pre-operative $v s$ post-operative values of $59 \%$ and $100 \%$, respectively, showing a $83 \%$ preoperative/post-operative agreement. Seki et al. ${ }^{59}$, among 91 OSCC patients treated with surgery alone or preoperative chemotherapy and resection, analysed 44 undergoing exclusive surgery. They evaluated TT, TB Score (TBS, Tab. III), infiltrative pattern (INF, Tab. III) and LVI, and found that the depth of infiltration measured on biopsies was lower than that on post-operative samples, while there was a good correlation of budding score in pre-treatment and post-treatment samples. Seki Soda et al. ${ }^{60}$ recently analysed the relationship between TBS in biopsies and in resected specimens of 248 patients with OSCC and the effect of pre-operative chemotherapy on TBS. The authors did not report staging, but pointed out that 141 of 248 patients received preoperative chemotherapy. The mean TBS in biopsy and resected specimens showed no significant difference between patients with and without preoperative chemotherapy. Moreover, they found that pre-operative chemotherapy is effective in lowering the budding score and suppressing relapses. 
Table II. Evaluation of pathological markers on biopsy and postoperative samples in the 6 papers selected (continues on page 113)

\begin{tabular}{|c|c|c|c|c|}
\hline Author & $\begin{array}{l}\text { Study design } \\
\text { Time period }\end{array}$ & $\begin{array}{l}\text { Site } \\
\text { Stage or TNM } \\
\text { teatment }\end{array}$ & $\begin{array}{l}\text { No. patients } \\
\text { Biopsy } \\
\text { technique }\end{array}$ & Aim of the study \\
\hline $\begin{array}{l}\text { Almangush, } \\
2018^{58}\end{array}$ & $\begin{array}{c}\text { Retrospective } \\
1981-2016\end{array}$ & $\begin{array}{l}\text { Mobile oral tongue } \\
\text { Stage I-II = } 81 \% \\
\text { Stage III-IV }=19 \% \\
\text { Surgery }=100 \%\end{array}$ & $\begin{array}{l}100 \\
\text { Incisional } \\
\text { biopsy }\end{array}$ & $\begin{array}{c}\text { Analysis of the sensitivity and specificity } \\
\text { of BD scores on biopsy and postoperative } \\
\text { samples }\end{array}$ \\
\hline Seki, $2016^{59}$ & $\begin{array}{c}\text { Retrospective } \\
\text { 2009-2013 }\end{array}$ & $\begin{array}{l}\text { Tongue, floor of the mouth } \\
\text { T1 } 1=43 \% \\
\text { T2-T4 }=57 \% \\
\text { Preop CT }=52 \% \\
\text { Surgery }=48 \%\end{array}$ & $\begin{array}{c}91 \\
\text { Not described }\end{array}$ & $\begin{array}{c}\text { Detection of histopathologic } \\
\text { parameters predictive for } \\
\text { Iympho nodal metastases in preoperative } \\
\text { biopsy specimens }\end{array}$ \\
\hline $\begin{array}{l}\text { Seki Soda, } \\
201960\end{array}$ & $\begin{array}{c}\text { Retrospective } \\
\text { 2009-2015 }\end{array}$ & $\begin{array}{c}\text { Oral cavity } \\
\text { Stage not reported } \\
\text { Preop CT }=57 \% \\
\text { Surgery }=43 \%\end{array}$ & $\begin{array}{l}248 \\
\text { Incisional } \\
\text { biopsy }\end{array}$ & $\begin{array}{l}\text { Evaluation of relashionship between } \\
\text { tumour budding score in biopsy and } \\
\text { resected specimens and the effect of } \\
\text { pre-op chemotherapy on tumour budding }\end{array}$ \\
\hline Seki, $2017^{48}$ & $\begin{array}{c}\text { Retrospective } \\
\text { 2009-2014 }\end{array}$ & 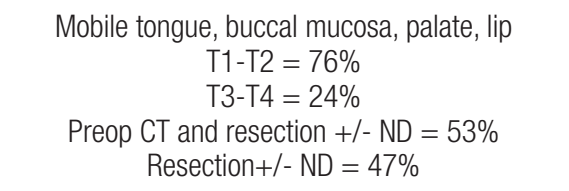 & $\begin{array}{l}209 \\
\text { Incisional } \\
\text { biopsy }\end{array}$ & $\begin{array}{l}\text { Evaluation of the relashionship between } \\
\text { tumour budding in biopsy specimen and } \\
\text { lymphnode metastases }\end{array}$ \\
\hline Nayanar, $2019^{61}$ & $\begin{array}{c}\text { Retrospective } \\
2014-2016\end{array}$ & 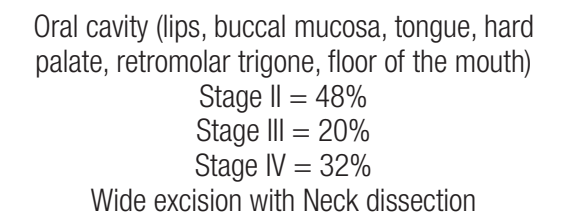 & $\begin{array}{c}160 \\
\text { Incision or } \\
\text { wedge biopsy }\end{array}$ & $\begin{array}{c}\text { Identification of clinical and } \\
\text { histopathological predictors of lymphnode } \\
\text { metastases } \\
\text { Development of a predictive scoring } \\
\text { system }\end{array}$ \\
\hline Sahoo, 202049 & $\begin{array}{l}\text { Retrospective } \\
2014-2016\end{array}$ & $\begin{array}{l}\text { Oral cavity (GB sulcus, tongue, floor of the mouth, } \\
\text { retromolar and maxilla) } \\
\text { cT1/T2 } \\
\text { Resection and elective neck dissection }\end{array}$ & $\begin{array}{l}150 \\
\text { Excisional } \\
\text { biopsy }\end{array}$ & $\begin{array}{c}\text { Comparison of prognostic performance of } \\
\text { TT and of DOI (TT2 and TT3) in predicting } \\
\text { lymphnode metastases. } \\
\text { Predictive potential of PNI and LVI }\end{array}$ \\
\hline
\end{tabular}

Predictive value of pathological markers in biopsy samples. Four papers 48,49,59,61 evaluated whether markers assessed on biopsy samples were predictive of lymph node metastases (Tab. II). Seki et al. ${ }^{59}$ examined 33 patients with tongue and floor SCC treated with tumour resection and neck dissection. They found that BD score $\geq 3$ and TT $>3 \mathrm{~mm}$ was significantly predictive of nodal metastases, overall survival (OS) and relapse-free survival (RFS), while TT alone measured on biopsy samples was not. The same team ${ }^{48}$ evaluated TBS on a larger series of 209
OSCC patients $(76 \%$ cT1) treated with resection or with pre-operative chemotherapy and resection, without stratifying the patients according to treatment modalities. They found that $\geq 3$ buds in the biopsy samples was predictive of lymph node metastases, and that TBS was significantly correlated with INF, Grading and LVI $(\mathrm{p}<0.01)$. The authors pointed out that the TB cut-off point needs to be defined, and that the evaluation of TBS and TT needs to be standardised. Nayanar et al. ${ }^{61}$ analysed 160 patients with oral cancer (Stage II $=48 \%$ ) treated with wide excision 
Table II. Evaluation of pathological markers on biopsy and postoperative samples in the 6 papers selected (follows from page 112)

Markers

TB

TT

BD model score

Depth of invasion (TT) Histologic differentiation
Budding score

Shape of rete pegs Pattern of invasion Site of cancer

Histologic Grading
TT
INF
LIV
Budding score

TB
INF
Tumour grade
$\prod$

TT1, TT2, TT3, DOI PNI, LVI
Results
Notes
BD model score

preo-op vs post-op

- Sensitivity $59.1 \%$

- Specificity $=100 \%$

- Agreement pre/post op = 83\%

Depth values $(\mathrm{mm})$

pre-op $($ mean $)=4.1(0.5-10 \mathrm{~mm})$

post-op (mean) $=6.3(0.5-23 \mathrm{~mm})$

Tumour depth: higher in resection specimens than in biopsy samples. It is predictive of lymph node metastases on resection specimens, not on biopsy samples

Budding score: good correlation between biopsy and postop specimens $\mathrm{BD}=>3$ and Tumour depth $>3 \mathrm{~mm}$ significantly predictive of lymph node metastases, OS and RFS

$\mathrm{BD}=>3$ and INFa/INFb: predictive of early or late lymph node metastases or late in many cases

Mean budding scores: no significant differences in both groups; but tended to increase in resected patients without preop CT

Preoperative CT-S1 treatment is effective for suppressing relapse and lowering the budding scores

$\mathrm{TB}=>3$ predictive of Lymphnode metastases and poor prognosis $\mathrm{P}<0.01$ ( mainly $\mathrm{T} 1-\mathrm{T} 2 \mathrm{cN} 0$ )

The budding score (high) together with INF and LIV were found to be independent risk factors for lymphnode metastases at multivariate analyses

Strong correlation $(p<0.01)$ between the budding score and tumour grade, tumour depth, INF, and blood vessels invasion

TB in early OSCC can be used as a reliable parameter for stratifying patients with different risks of lymph node metastases

Risk score (4-18)

Score 4: predictive of $\mathrm{N}+=5 \%$

Score 18: predictive of $\mathrm{N}+=91 \%$
$17 \%=$ non-representative biopsies (badly fragmented, too superficial, technical artifacts) TB and TT (Tab. I) Budding model score (Tab. II)

Tा (Tab. I)

INF (Tab. I)

Budding score (Tab. Ilb)

Comparison between TB, TT, and INF status on lymph node metastases was assessed on 33 patients who underwent resection and neck dissection

Budding score (Tab. II)

Authors describe biopsy technique; Tumour budding can be detected using routine haematoxylin and eosin-stained slides or cytokeratin-stained slides.

Results may differ significantly depending on the staining used

The risk score needs to be tested and validated in other patient populations Rete pegs (Tab. I) Risk score (Tab. II) and neck dissection and proposed a predictive score based on selected pathological features (rete pegs, pattern of invasion, TT, histologic differentiation) and site of tumour (buccal mucosa, tongue, other). The score ranged from 4 to 18; the authors found that a score of 4 is predictive of risk for lymph node metastasis of 5\%; for scores of 10, 14 and 18 , the risk was $31 \%, 67 \%$ and $91 \%$, respectively. Sahoo et al. ${ }^{49}$ studied $150 \mathrm{cT} 1-\mathrm{T} 2$ patients treated with resection and neck dissection for OSCC. They compared three measurement modalities of the depth of invasion: TT1, TT2 (DOI) and TT3 (alternative DOI); according to the authors, TT2 corresponds to DOI, as defined in the TNM $8^{\text {th }}$ Edition ${ }^{37,38}$. They found that TT2 (DOI) and LVI correlate with nodal metastases.

\section{Discussion}

To our knowledge, this is the first comprehensive review correlating biological tumour characteristics between biopsy and corresponding pathologic specimen with an evidence-based method. Unfortunately, the studies that met 
Table III. Different scores for prognostic evaluation.

\begin{tabular}{|c|c|c|}
\hline Author & Definition & Score \\
\hline Almangush, $2018^{58}$ & $\begin{array}{l}\text { BD Model Score (BDM): } \\
\mathrm{N}^{\circ} \text { of buds and depth of invasive front (IF, mm) }\end{array}$ & $\begin{array}{l}0:<5 \text { buds at the IF and depth }<4 \mathrm{~mm} \\
1:=/>5 \text { buds at the IF or depth }>4 \mathrm{~mm} \\
2:=/>5 \text { buds at the IF and depth }>4 \mathrm{~mm}\end{array}$ \\
\hline Seki, $2017{ }^{48}$ & $\begin{array}{l}\text { Tumour Budding Score (TBS): } \\
\text { Number of buds }\end{array}$ & $\begin{array}{l}\text { Low: }<3 \text { cells } \\
\text { Intermediate: } 3-4 \text { cells } \\
\text { High: }=>5 \text { cells }\end{array}$ \\
\hline Seki, $2017^{48}$ & $\begin{array}{l}\text { INF (Infiltrative Pattern): } \\
\text { Cancer growth and mode of invasion }\end{array}$ & $\begin{array}{l}\text { INFa: Expanding growth with a distinct border from surrounding } \\
\text { tissue; } \\
\text { INFb: Intermediate pattern between INFa and INFc; } \\
\text { INFC: Infiltrative growth with no distinct border from the surrounding } \\
\text { tissue }\end{array}$ \\
\hline Nayanar, 201961 & $\begin{array}{l}\text { Risk Score: } \\
\text { Sum of single score of clinical and pathologic parameters }\end{array}$ & $\begin{array}{l}\text { Shape of rete pegs: Slender and fused }=1 \text {, Bulbous and uniform = 2; } \\
\text { Irregular }=3 \\
\text { Pattern of invasion: Pushing }=1 ; \text { Minimally invasive }=2 \text {; Frankly } \\
\text { invasive }=5 \\
\text { Depth of invasion }(T T, \mathrm{~mm}): 0-3=1 ;>3=3 \\
\text { Histogic differentiation: Well }=1 ; \text { Moderate }=3 ; \text { Poor }=5 \\
\text { Site of cancer: Buccal mucosa }=0 ; \text { Tongue }=1 ; \text { Others }=2\end{array}$ \\
\hline
\end{tabular}

the inclusion criteria had a level of evidence of 3 and 4 according to the AJCC on Cancer Levels of Evidence classification ${ }^{20}$. It is worth stressing a criticality common to all: namely that they differ in the design of the study, selection of patients, oral subsite of cancer and in choice of pathological markers such as DOI, TT and budding score; for this reason, the results are not comparable. Furthermore, many authors have measured the depth of the invasion differently than what is foreseen in the TNM $8^{\text {th }}$ Edition, even when published after its release. In this regard, the paper of Driven et al. that quantified the impact of the stage migration on patients' prognosis using TT and DOI in a retrospective cohort of 456 OSCC patients is interesting. They found similar stage category and prognosis regardless of the measurement used ${ }^{62}$. This review highlights several other critical issues.

\section{Biopsy technique}

The patients evaluated by Almangush ${ }^{58}$, Seki ${ }^{48}$ and Seki-Soda ${ }^{60}$ underwent incisional biopsy; those studied by Nayanar ${ }^{61}$ had an incisional or wedge biopsy; those in the study of Sahoo ${ }^{49}$ were treated with an excisional biopsy. The authors did not provide more details on the procedures applied to perform the incisional/excisional biopsy. This information is important since the reliability of the biopsy sample strictly depends on the quality and quantity of the tissue taken. Seki et al. ${ }^{59}$ did not specify the biopsy modalities in their first report, but in a later study aimed to evaluate the relationship between TBS assessed in OSCC biopsy specimens and lymph node metastases (LNM), recommending that incisional biopsy be per- formed peripherally to the cancer so as to obtain a significant amount of non-necrotic tissue from the centre of the tumour ${ }^{48}$.

\section{Depth of biopsy}

It should also be stressed that the biopsy sample should be deep enough to possibly include the entire tumour infiltration front and underlying healthy tissue ${ }^{48}$. Reliability of biopsy (incisional, wedge, punch, excisional) is influenced by the depth of the sample because it is unlikely that specimens always include tumour stroma on the invasive front, which is adequate to evaluate the relationships between the various components of the tumour microenvironment (TME) ${ }^{48,58,59}$. In fact, tissue biomarkers are the morphological expression of the TME, or the field in which the immune system and the tumour interplay. Inside TME cancer cells, non-tumour cells and stroma are in a continuous and dynamic relationship, and any change within the TME may reflect changes of the balance between the immune system and tumour ${ }^{63}$. In this context, the role of biopsy is not only diagnostic, but also predictive, since biopsies should include the invasive front, the behaviour of tumour cells in the TME interface and biomarkers that provide useful information to guide the therapeutic choice ${ }^{15,64,65-67}$. Leite et al. ${ }^{66}$, in a recent preliminary study on biopsy samples from 56 OSCC cases, highlighted the possible importance of the correlation between grading, predominant mode of invasion and TB intensity. The authors classified the mode of invasion in 4 degrees, similar to the proposal of Shimu$\mathrm{Zu}^{54}$; they also graded TB as low-intensity ( 5 buds in one single x200 power field) and high- intensity ( $\geq 5$ buds in 
one single $\mathrm{x} 200$ power field). The majority of cases studied (66.1\%) were high-intensity TB; all cases with the worst mode of invasion showed high-intensity TB, while no association was found between TB and histopathological grading. They concluded that both TB and mode of invasion in OSCC diagnostic specimens could help to select patients who could benefit from more aggressive treatment. This paper has some critical issues, such as the biopsy performed in the central part of the tumour, which is rich in necrotic tissue that must be eliminated, and the lack of follow-up. Therefore, these promising data require confirmation on larger series with a longer follow-up. A large biopsy on the surface (at least $8 \mathrm{~mm}$ ) and depth (at least $5 \mathrm{~mm}$ ) could allow an assessment of the microenvironment in early cancers, but does not solve the problem ${ }^{48,64}$. In this regard, Dhanda ${ }^{64}$ compared TT measurement on biopsies and the corresponding post-operative samples reported in the medical records of 93 patients operated on for oral cancer; we have not included this paper in our review according to the exclusion criteria (point c) because those specimens were not revised by a pathologist. However, measurements reported in medical charts provide interesting information because in this series $20 \%$ of tumours had a tumour depth $>10 \mathrm{~mm}$ on post-operative specimens; on biopsies only $28 \%$ of samples had a thickness greater than the DOI calculated on the post-operative specimens. They therefore suggested performing a $10 \mathrm{~mm}$ deep punch biopsy, which should potentially include the invasive front in up to $80 \%$ of the cases analysed in this paper ${ }^{64}$.

\section{Additional biopsy related issues}

It should also be pointed out that $17 \%$ of biopsy samples are not representative of the cancer due to technical errors such as fragmented, superficial, non-orientable samples and artifacts in the preparation of slides ${ }^{58}$. For this reason, how the specimen is sectioned and oriented is important: slides are evaluable if sections are perpendicular and include all mucous, submucosal and muscle layers. On the contrary, tangential sectioning does not allow the evaluation of infiltration depth ${ }^{68}$. In addition, biopsy and surgical procedures can sometimes make it difficult to measure the depth of invasion on post-operative specimens. This critical point is underlined by Berdugo who analysed the postoperative samples of 239 glossectomies ${ }^{69}$ : $5 \%$ had only a minimal residual of cancer and in $14 \%$ no tumour was found. He also emphasised that in 21/183 (11.5\%) pT2 OSCCs the DOI was underestimated due to positivity of deep resection margins. Finally, it should be kept in mind that a large surgical biopsy may create an inflammatory reaction which alters the microenvironment and could promote the regional spread of cancer ${ }^{70,71}$.

\section{Changing the aim of biopsy}

To plan the best treatment of a tumour, one must know its histopathological diagnosis, site, size and biological aggressiveness. Currently, the risk of developing lymph node metastases can be evaluated by measuring biomarkers such as Grading, PNI, LVI, positive resection margins, depth and mode of invasion and tumour budding on post-operative specimens. On the basis of this information, high-risk patients can be identified for treatment with post-operative radiotherapy or chemoradiotherapy. It is hoped that this predictive and prognostic information will be available for all patients, even those candidates for non-surgical therapies, at the end of the diagnostic process, so as to personalise the therapy for each. This review documents the possibility to reliably test these tissue biomarkers on biopsy samples. However, it is necessary that the biopsy technique and the methods of evaluation of biomarkers are standardised and validated in clinical trials on large case series before they can be used in clinical practice. For these reasons, the role of biopsy is changing and evaluation of a biopsy sample will allow not only to define the morphology of a tumour, but also to guide the therapeutic choice.

\section{Clinical and imaging evaluation of depth of infiltration}

The $8^{\text {th }}$ edition of TNM suggests that the DOI of oral cancer is assessed pre-operatively with clinical and imaging investigations ${ }^{38}$. It should be emphasised that clinical evaluation is subjective, depends on the experience and ability of each physician and is limited by anatomical conditions such as trismus and/or the patient's intolerance to palpation for pain ${ }^{72}$. Recently, prospective studies comparing pre-operative clinical and magnetic resonance imaging (MRI) evaluation ${ }^{72}$, or MRI alone ${ }^{50,73,74}$ with post-operative DOI have documented a good correlation of these investigations, especially in tumours with infiltration $>5 \mathrm{~mm}$. On the contrary, other authors have reported an overestimation of $\mathrm{T} 2$ lesions and underestimation of T4 cancers when clinical T staging is compared with histopathological data ${ }^{75,76}$. These papers also highlight several critical issues related to imaging (MRI/ computed tomography, CT) such as artifacts due to movement and dental fillings; the evaluation of peritumoural oedema and inflammation, and timing between imaging and biopsy (first imaging or biopsy? If imaging is performed after biopsy, how long does it take to get reliable information from MRI/CT?) ${ }^{50,76,77}$. Tumour shrinkage of formalin-fixed post-operative specimens may interfere with comparing the DOI between MRI pre-operative imaging and post-operative specimens ${ }^{72,78}$. A recent metaanalysis ${ }^{79}$ documented a high correlation of TT measured by intraoral ultrasound and histopathology mainly in 
T1-2 tongue cancers $(\mathrm{p}<0.001)$, although it is operatordependent and often overestimates exophytic tumours ${ }^{80,81}$.

\section{Future directions}

Other non-invasive diagnostic modalities are being considered to support evidence-based clinical decision-making, in particular radiomics and liquid biopsy.

Radiomics is an emerging translational field of research. Thanks to the extraction of mathematically defined parameters from routine medical images it is possible to generate large-scale sets of information that can be correlated with OS and treatment-related toxicity and can also be used to identify new biomarkers to be implemented in daily clinical practice ${ }^{82}$. Currently, there are few but promising published studies on the application of radiomics in oral cancer with CT or MRI ${ }^{83-85}$. Probably, if the role of radiomics will be confirmed with standardised methodology on a large number of patients, these results would help to promote cancer treatment towards personalised precision medicine ${ }^{82,86}$.

Liquid biopsy is particularly promising as an alternative to surgical biopsy. It allows assessment of biomarkers in fluids (serum, saliva, urine, etc.) such as circulating tumour cells (CTC), DNA and RNA fragments (miRNA), exosomes that originate from cancerous cells, and their characteristics, particularly mutations and number of somatic alterations ${ }^{87-90}$. Liquid biopsy theoretically provides the individual molecular profile of each cancer over time, and could allow physicians to diagnose a tumour, plan tailored therapy and monitor cancer evolution ${ }^{91,92}$. Unfortunately, no circulating biomarker has yet been validated for routine use in clinical practice for OSCC, because alongside the promising potentials, there are also considerable critical issues ${ }^{93,94}$. For example, the levels of circulating DNA fragments derived from the tumour (cfDNA) represent a small fraction (up to $10 \%$ ) of the total cfDNA and variations between patients related to cancer stage, tumour vascularisation, tumour burden and apoptosis rate can compromise the accuracy of the tests ${ }^{92,95-97}$.

\section{Conclusions}

The traditional role of biopsy is evolving; in the future, a single procedure will allow to define the histology of a tumour and to identify predictive and prognostic biomarkers. The data emerging from this review of the literature, even if heterogeneous and fragmented, suggest that the evaluation of markers on biopsy samples, mainly the DOI and growth characteristics of the invasive front (INF, TB) could provide useful indications for planning tailored treatments. Minimally invasive procedures such as liquid biopsy are also promising, although only preliminary results are currently available which require further confirmation. Further clinical studies are needed to standardise and validate clinical and imaging evaluation, surgical and liquid biopsy technique, sampling of specimens, and choice of biomarkers and their assessment before introducing these diagnostic and predictive modalities in daily clinical practice.

\section{References}

1 Ferlay J, Colombet M, Soerjomaratam I, et al. Estimating the global cancer incidence and mortality in 2018: GLOBOCAN sources and methods. Int J Cancer 2019;144:1941-1953. https://doi.org/10.1002/ ijc. 31937

2 Wu K, Wei J, Liu Z, et al. Can pattern and depth of invasion predict lymph node relapse and prognosis in tongue squamous cell carcinoma. BMC Cancer 2019;9:714. https://doi.org/10.1186/s12885-019$5859-\mathrm{y}$

3 Fitzmaurice C, Abate D, Abbasi N, et al. Global burden of disease cancer collaboration global, regional, and national cancer incidence, mortality, years of life lost, years lived with disability and disabilityadjusted life-years for 29 cancer groups. 1990 to 2017. Jama Oncol 2019;5:1749-1768. https://doi.org/10.1001/jamaoncol.2019.2996

4 Chen SW, Zhang Q, Guo ZM, et al. Trends in clinical features and survival of oral cavity cancer: fifty years of experience with 3,362 consecutive cases from a single institution. Cancer Manag Res 2018;10:4523-4535. https://doi.org/10.2147/CMAR.S171251

5 Paderno A, Morello R, Piazza C. Tongue carcinoma in young adults: a review of the literature. Acta Otorhinolaryngol Ital 2018;38:175-180. https://doi.org/10.14639/0392-100X-1932

6 Kharwala SS, Hatsukami DK, Stepanov I, et al. Patterns of tobacco cessation attempts and symptoms experienced among smokers with head and neck squamous cell carcinoma. JAMA Otolaryngol Head Neck Surg 2018;144:477-482. https://doi.org/10.1001/jamaoto. 2018.0249

7 Bala MM, Strzeszynski L, Topor-Madry R, et al. Mass media interventions for smoking cessation in adults. Cochrane Database Syst Rev 2013;6:CD004704. https://doi.org/10.1002/14651858.CD004704.pub3

8 Challapalli SD, Simpson MC, Adjei Boakye E, et al, Head and neck squamous cell carcinoma in adolescents and young adults: survivorship patterns and disparities. J Adolesc Young Adult Oncol 2018;7:472-479. https://doi.org/10.1089/jayao.2018.0001

$9 \mathrm{Ng}$ HJ, Iyer NG, Tan MH, et al. Changing epidemiology of oral squamous cell carcinoma of the tongue: a global study. Head Neck 2017;39:297-304. https://doi.org/10.1002/hed.24589

10 Hussein AA, Helder MN, de Visscher JG, et al. Global incidence of oral and oropharynx cancer in patients younger than 45 years versus older patients: a systematic review. Eur J Cancer 2017;82:115-127. https://doi.org/10.1016/j.ejca.2017.05.02.6

11 Yete S, D'Souza W, Saranath D, et al. High-risk human papillomavirus in oral cancer: clinical implications. Oncology 2018;94:133-141. https://doi.org/10.1159/000485322

12 Hübbers CU, Akgül B. HPV and cancer of the oral cavity. Virulence 2015;6:244-248. https://doi.org/10.1080/21505594.2014.999570

13 Russo D, Merolla F, Varricchio S, et al. Epigenetics of oral and oropharyngeal cancers (Review). Biomed Rep 2018;9:275-283. https:// doi.org/10.3892/br.2020.1290

14 Lam DK, Schmidt BL. Molecular biology of head and neck cancer: therapeutic implications. In: Bagheri SC, Bell RB, Khan HA, editors. Current therapy in oral and maxillofacial surgery. Amsterdam: 
Elsevier Inc; 2012. pp. 92-101. https://doi.org/10.1016/B978-1-41602527-6.00010-4

15 Zhu Y, Liu H, Xie N, et al. Impact of tumour budding in head and neck squamous cell carcinoma: a meta-analysis. Head Neck 2019;41:542550. https://doi.org/10.1002/hed.25462

16 Naruse T, Yanamoto S, Matsushita Y, et al. Cetuximab for the treatment of locally advanced and recurrent/metastatic oral cancer: an investigation of distant metastasis. Mol Clin Oncol 2016;5:246-252. https://doi.org/10.3892/mco.2016.928

17 Weinstein JN, Collisson EA, Mills GB, et al. The Cancer Genome Atlas pan-cancer analysis project. Nat Genet 2013;45:113-120. https:// doi.org/10.1038/ng.2764

18 Leichsering J, Horak P, Kreutzfeldt S, et al. Variant classification in precision oncology. Int J Cancer 2019;145:2996-3010. https://doi. org/10.1002/ijc.32358

19 Sankar PL, Parker LS. The Precision Medicine Initiative's All of Us Research Program: an agenda for research on its ethical, legal, and social issues. Genet Med 2017;19:743-750. https://doi.org/10.1038/ $\operatorname{gim} .2016 .183$

20 Amin MB, Greene, FL, Edge SB, et al. The Eighth Edition AJCC Cancer Staging Manual: continuing to build a bridge from a population-based to a more "personalized" approach to cancer staging. Ca Cancer J Clin 2017;67:93-99. https://doi.org/10.3322/caac.21388

21 NCCN Clinical Practice Guidelines in Oncology. Head and Neck Cancers v 1-2020 - February 12, 2020. NCCN.org.

22 Orlandi E, Alfieri S, Simon C, et al. Treatment challenges in and outside a network setting: head and neck cancers. Eur J Surg Oncol 2019;45:40-45. https://doi.org/10.1016/j.ejso.2018.02.007

23 Orlandi E, Licitra L. Personalized medicine and the contradictions and limits of first-generation deescalation trials in patients with $\mathrm{Hu}-$ man Papillomavirus-positive oropharyngeal cancer. JAMA Otolaryngol Head Neck Surg 2018;144:99-100. https://doi.org/10.1001/ jamaoto.2017.2308

24 Coyle KM, Boudreau JE, Marcato P. Genetic mutations and epigenetic modifications driving cancer and informing Precision Medicine. Biomed Res Int 2017;2017:9620870. https://doi. org/10.1155/2017/9620870

25 Garraway LA, Verweij J, Ballman KV. Precision oncology: an overview. J Clin Oncol 2013;31:1803-1805. https://doi.org/10.1200/ JCO.2013.49.4799

26 Zhong L, Liu Y, Wang K, et al. Biomarkers: paving stones on the road towards the personalized precision medicine for oral squamous cell carcinoma. BMC Cancer 2018;18:911. https://doi.org/10.1186/ s12885-018-4806-7

27 Nor JE, Gutkind JS. Head and neck cancer in the new era of precision medicine. J Dent Res 2018;97:601-602. https://doi. org/10.1177/0022034518772278

28 Giefing M, Wierzbicka M, Szyfter K, et al. Moving towards personalized therapy in head and neck squamous cell carcinoma through analysis of next generation sequencing data. Eur J Cancer 2016;55:147157. https://doi.org/10.1016/j.ejca.2015.10.070

29 Bernier J, Domenge C, Ozsahin M, et al. Postoperative irradiation with or without concomitant chemotherapy for locally advanced head and neck cancer. N Engl J Med. 2004;350:1945-1952. https://doi. org/10.1056/NEJMoa032641

30 Cooper JS, Pajak TF, Forastiere AA, et al. Postoperative concurrent radiotherapy and chemotherapy for high-risk squamous-cell carcinoma of the head and neck. N Engl J Med. 2004;350:1937-1944. https:// doi.org/10.1056/NEJMoa032646

31 Bernier J, Cooper JS, Pajak TF et al. Defining risk levels in locally advanced head and neck cancers: a comparative analysis of concurrent postoperative radiation plus chemotherapy trials of the EORTC
(\#22931) and RTOG (\#9501). Head Neck 2005;27:843-850. https:// doi.org/10.1002/hed.20279

32 Cooper JS, Zhang Q, Pajak TF, et al. Long-term follow-up of the RTOG 9501/intergroup phase III trial: postoperative concurrent radiation therapy and chemotherapy in high-risk squamous cell carcinoma of the head and neck. Int J Radiat Oncol Biol Phys 2012;84:11981205. https://doi.org/10.1016/j.ijrobp.2012.05.008

33 Chen WC, Lai CH, Fang CC, et al. Identification of high-risk subgroups of patients with oral cavity cancer in need of postoperative adjuvant radiotherapy or chemo-radiotherapy. Medicine (Baltimore) 2016;95(22):e3770. https://doi.org/10.1097/MD.0000000000003770

34 Fan KH, Chen YC, Lin CY, et al. Postoperative radiotherapy with or without concurrent chemotherapy for oral squamous cell carcinoma in patients with three or more minor risk factors: a propensity score matching analysis. Radiat Oncol 2017;12:184. https://doi. org/10.1186/s13014-017-0910-0

35 Cheraghlou S, Schettino A, Zogg CK, et al. Changing prognosis of oral cancer: an analysis of survival and treatment between 1973 and 2014. Laryngoscope 2018;128:2762-2769. https://doi.org/10.1002/ lary. 27315

36 Ribeiro IP, Caramelo F, Esteves L, et al. Genomic and epigenetic signatures associated with survival rate in oral squamous cell carcinoma patients. J Cancer 2018;9:1885-1895. https://doi.org/10.7150/ jca.23239

37 Amin MB, Edge S, Greene F, et al. AJCC Cancer Staging Manual. Eigth Edition. New York: Springer International Publishing; 2017.

38 Lydiatt WM, Patel SG, O'Sullivan B, et al. Head and neck cancers. Major changes in the American Joint Committee on Cancer eighth edition Cancer Staging Manual. Ca Cancer J Clin 2017;67:122-137. https://doi.org/10.3322/caac.21389

39 Fakih AR, Rao RS, Borges AM, et al. Elective versus therapeutic neck dissection in squamous carcinoma of tongue a prospective randomized trial. Am J Surg 1989;158:309-313. https://doi.org/10.1016/00029610(89)90122-0

40 Fukano H Matsuura H Hasegawa Y, et al. Depth of invasion as a predictive factor for cervical lymph node metastasis in tongue carcinoma. Head Neck 1997;19:205-10. https://doi.org/10.1002/(sici)10970347(199705)19:3<205::aid-hed7>3.0.co;2-6

${ }^{41}$ Kukreja P, Parekh D, Roy P. Practical challenges in measurement of invasion in oral squamous cell carcinoma: pictographical documentation to improve consistency of reporting per the AJCC $8^{\text {th }}$ Edition recommendations. Head Neck Pathol 2020;14:419-427. https://doi. org/10.1007/s12105-019-01047-9

42 Almangush A, Bello IO, Coletta RD, et al. For early-stage oral tongue cancer, depth of invasion and worst pattern of invasion are the strongest pathological predictors for locoregional recurrence and mortality. Virchows Arch 2015;467:39-46. https://doi.org/10.1007/s00428-015$1758-\mathrm{z}$

43 Larson AR, Kemmer J, Formeister E, et al. Beyond depth of invasion: adverse pathologic tumour features in early oral tongue squamous cell carcinoma. Laryngoscope 2020;130:1715-1720. https://doi. org/10.1002/lary.28241.

44 den Toom IJ, Janssen LM, van Es RJJ, et al. Depth of invasion in patients with early stage oral cancer staged by sentinel node biopsy. Head Neck 2019;41:2100-2106. https://doi.org/10.1002/hed.25665

45 Almangush A, Pirinen M, Heikkinen I, et al. Tumour budding in oral squamous cell carcinoma: a meta-analysis. Br J Cancer 2018:118:577586. https://doi.org/10.1038/bjc.2017.425

46 Almangush A, Heikkinen I, Bakhti N, et al. Prognostic impact of tumour -stroma ratio in early-stage oral tongue cancers. Histopathology 2018;72:1128-1135. https://doi.org/10.1111/his.13481

47 Hori Y, Kubota A, Yokose T, et al. Association between pathologi- 
cal invasion patterns and late lymph node metastases in patients with surgically treated clinical N0 early tongue carcinoma. Head Neck 2020;42:238-243. https://doi.org/10.1002/hed.25994

48 Seki M, Sano T, Yokoo S, et al. Tumour budding evaluated in biopsy specimens is a useful predictor of prognosis in patients with cN0 early stage oral squamous cell carcinoma. Histopathology 2017;70:869879. https://doi.org/10.1111/his.13144

49 Sahoo A, Panda S, Mohanty N, et al. Perineural, lymphovascular and depths of invasion in extrapolating nodal metastasis in oral cancer. Clin Oral Investig 2020;24:747-755. https://doi.org/10.1007/s00784019-02921-0

50 Vidiri A, Panfili M, Boellis A, et al. The role of MRI-derived depth of invasion in staging oral tongue squamous cell carcinoma: inter-reader and radiological-pathological agreement. Ann Radiol 2020;61:344352. https://doi.org/10.1177/0284185119862946

51 Prall F. Tumour budding in colorectal carcinoma. Histopathology 2007;50;151-162. https://doi.org/10.1111/j.1365-2559.2006.02551.x

52 Jensen DH, Dabelsteen E, Specht L, et al. Molecular profiling of tumour budding implicates TGFb-mediated epithelial-mesenchymal transition as a therapeutic target in oral squamous cell carcinoma. J Pathol 2015;236:505-516. https://doi.org/10.1002/path.4550

53 Attramadal CG, Kumar S, Boysen ME, et al. Tumour budding, EMT and cancer stem cells in T1-2/N0 oral squamous cell carcinomas. Anticancer Res 2015; 35:6111-6120.

54 Shimizu S, Miyazaki A, Sonoda T, et al. Tumour budding is an independent marker in early stage oral squamous cell carcinoma: with special reference to the mode of invasion and worst pattern of invasion. Plos One 2018;13:e0195451. https://doi.org/10.1371/journal. pone. 0195451

55 Almangush A, Youssef O, Pirinen H, et al. Does evaluation of tumour budding in diagnostic biopsies have a clinical relevance? A systematic review. Histopathology 2019;74:536-544. https://doi.org/10.1111/ his. 13793

56 Wang K, Ma W, Wang J, et al. Tumour-stroma ratio is an independent predictor for survival in esophageal squamous cell carcinoma. J Thorac Oncol 2012;7:1457-1461. https://doi.org/10.1097/ JTO.0b013e318260dfe 8

57 Wu J, Liang C, Chen M, et al. Association between tumour-stroma ratio and prognosis in solid tumour patients: a systematic review and meta-analysis. Oncotarget 2016;7:68954-68965. https://doi. org/10.18632/oncotarget.12135

58 Almangush A, Leivo I, Siponen M, et al. Evaluation of the budding and depth of invasion (BD) model in oral tongue cancer biopsies. Virchows Arch 2018;472:231-236. https://doi.org/10.1007/s00428-0172212-1

59 Seki M, Sano T, Yokoo S, et al. Histologic assessment of tumour budding in preoperative biopsies to predict nodal metastasis in squamous cell carcinoma of the tongue and floor of the mouth. Head Neck 2016;38:E1582-1590. https://doi.org/10.1002/hed.24282

60 Seki-Soda M, Sano T, Koshi H, et al. Histopathological changes in tumour budding between biopsy and resected specimens from patients treated with preoperative S-1 chemotherapy for oral cancer. J Oral Pathol Med 2019;48:880-887. https://doi.org/10.1111/jop.12923

${ }_{61}$ Nayanar SK, Tripathy JP, Duraisamy K, et al. Prognostic efficiency of clinicopathologic score to predict cervical ymph node metastasis in oral squamous cell carcinoma. J Oral Maxillofac Pathol 2019;23:3642. https://doi.org/10.4103/jomfp.JOMFP_132_17

62 Dirven R, Ebrahimi A, Moeckelmann N, et al. Tumour thickness versus depth of invasion - Analysis of the $8^{\text {th }}$ edition American Joint Committee on Cancer Staging for oral cancer. Oral Oncol 2017;74:3033. https://doi.org/10.1016/j.oraloncology.2017.09.007

63 Merlano MC, Abbona A, Denaro N, et al. Knowing the tumour mi- croenvironment to optimise immunotherapy. Conference Paper. Acta Otorhinolaryngol Ital 2019;39:18-21. https://doi.org/10.14639/0392$100 \mathrm{X}-2481$

64 Dhanda J, Uppal N, Chowlia H, et al. Features and prognostic utility of biopsy in oral squamous cell carcinoma. Head Neck 2016;38:E18571862. https://doi.org/10.1002/hed.24335

65 Kolenda T, Przybyla W, Kapalczynska M, et al. Tumour microenvironment - Unknown niche with powerful therapeutic potential. Rep Pract Oncol Radiother 2018;23:143-153. https://doi.org/10.1016/j. rpor.2018.01.004

66 Leite CF, Silva KDD, Horta MCR, et al. Can morphological features evaluated in oral cancer biopsies influence in decision-making? A preliminary study. Pathol Res Pract 2020;216:153138. https://doi. org/10.1016/j.prp.2020.153138.

67 Elseragy A, Salo T, Coletta RD, et al. A proposal to revise the histopathologic grading system of early oral tongue cancer incorporating tumour budding. Am J Surg Pathol 2019;43:703-709. https://doi. org/10.1097/PAS.0000000000001241

68 Heerema MGJ, Melchers LJ, Roodenburg JNL, et al. Reproducibility and prognostic value of pattern of invasion scoring in low-stage oral squamous cell carcinoma. Histopathology 2016;68:338-397. https:// doi.org/10.1111/his.12754

69 Berdugo J, Thompson LDR, Purgina B, et al. Measuring depth of invasion in early squamous cell carcinoma of the oral tongue: positive deep margin, extratumoural perineural invasion, and other challenges. Head Neck Pathol 2019;13:154-161. https://doi.org/10.1007/s12105018-0925-3

70 Seppala M, Tervo S, Pohjola K, et al. The association and prognostic relevance of cancerous inhibitor of protein phosphatase $2 \mathrm{~A}$ and inflammation in tongue squamous cell carcinoma. APMIS 2015;123:1007-1015. https://doi.org/10.1111/apm.12462

71 Lundqvist L, Stenlund H, Laurell G, et al. The importance of stroma inflammation in squamous cell carcinoma of the tongue. J Oral Pathol Med 2012;41:379-383. https://doi.org/10.1111/j.16000714.2011.01107.x

72 Alsaffar HA, Goldstein DP, King EV, et al. Correlation between clinical and MRI assessment of depth of invasion in oral tongue squamous cell carcinoma. J Otolaryngol Head Neck Surg 2016;45:61. https:// doi.org/10.1186/s40463-016-0172-0

73 Jayasankaran SC, Chelakkot PG, Karippaliyil M, et al. Magnetic resonance imaging: a predictor of pathological tumour dimensions in carcinoma of the anterior two-thirds of tongue. Prospective evaluation. Indian J Cancer 2017;54:508-513. https://doi.org/10.4103/ijc. IJC_319_17

74 Morand GB, Ikenberg K, Vital DG, et al. Preoperative assessment of CD44-mediated depth of invasion as predictor of occult metastases in early oral squamous cell carcinoma. Head Neck 2019;41:950-958. https://doi.org/10.1002/hed.25532

75 Goel V, Parihar PS, Parihar A, et al. Accuracy of MRI in prediction of tumour thickness and nodal stage in oral tongue and gingivobuccal cancer with clinical correlation and staging. J Clin Diagn Res 2016;10:TC01-5. https://doi.org/10.7860/ JCDR/2016/17411.7905

76 Mao MH, Wang S, Feng ZE, et al. Accuracy of magnetic resonance imaging in evaluating the depth of invasion of tongue cancer. A prospective cohort study. Oral Oncol 2019;91:79-84. https://doi. org/10.1016/j.oraloncology.2019.01.021

77 Franceschi L, Santo JM, Abreu AM, et al. Staging of oral cavity cancer in the 8th edition of the TNM classification: the role of computed tomography in the assessment of depth of invasion and extranodal extension. Arch Head Neck Surg 2018;47:e0869. https://doi. org/10.4322/ahns.2018.0869

78 Chen CH, Hsu MY, Jiang RS, et al. Shrinkage of head and neck cancer 
specimens after formalin fixation. J Chin Med Assoc 2012;75:109113. https://doi.org/10.1016/j.jcma.2012.02.006

79 Klein Nulent TJW, Noorlag R, Van Cann EM, et al. Intraoral ultrasonography to measure tumour thickness of oral cancer: a systematic review and meta-analysis. Oral Oncol 2018;77:29-36. https://doi. org/10.1016/j.oraloncology.2017

80 Tarabichi O, Bulbul MG, Kanamuri VV, et al. Utility of intraoral ultrasound in managing oral tongue squamous cell carcinoma: systematic review. Laryngoscope 2019;129:662-670. https://doi.org/ 10.1002/lary.27403

81 Iida Y, Kamijo T, Kusafuka K, et al. Depth of invasion in superficial oral tongue carcinoma quantified using intraoral ultrasonography. Laryngoscope 2018;128:2778-2782. https://doi.org/10.1002/lary.27305

82 Rizzo S, Botta F, Raimondi S, et al. Radiomics: the facts and the challenges of image analysis. Eur Radiol Exp 2018;2:36. https://doi. org/10.1186/s41747-018-0068-z

${ }_{83}$ Haider SP, Burtness B, Yarbrough WG, et al. Applications of radiomics in precision diagnosis, prognostication and treatment planning of head and neck squamous cell carcinomas. Cancers Head Neck 2020;5:6. https://doi.org/10.1186/s41199-020-00053-7

84 Mes SW, van Velden FHP, Peltenburg B, et al. Outcome prediction of head and neck squamous cell carcinoma by MRI radiomic signatures. Eur Radiol 2020;30:6311-6321. https://doi.org/10.1007/s00330-020-06962-y

85 Pan X, Zhang T, Yang Q, et al. Survival prediction for oral tongue cancer patients via probabilistic genetic algorithm optimized neural network models. Br J Radiol 2020;93:20190825. https://doi.org/10.1259/ bjr.20190825

86 Romeo V, Cuocolo R, Ricciardi C, et al. Prediction of tumor grade and nodal status in oropharyngeal and oral cavity squamous-cell carcinoma using a radiomic approach. Anticancer Res 2020;40:271-280. https:/doi.org/10.21873/anticanres.13949

87 Castagnola M, Scarano E, Passali GC, et al. Salivary biomarkers and proteomics: future diagnostic and clinical utilities. Acta Otorhinolaryngol Ital 2017;37:94-101. https://doi.org/10.14639/0392100x-1598
88 Xiao C, Song F, Zheng YL, et al. Exosomes in head and neck squamous cell carcinoma. Front Oncol 2019;9:894. https://doi. org/10.3389/fonc. 2019.00894

89 Cree IA, Uttley L, Buckley Woods H, et al. The evidence base for circulating tumour DNA blood-based biomarkers for the early detection of cancer: a systematic mapping review. BMC Cancer 2017;17:697. https://doi.org/10.1186/s12885-017-3693-7

90 Mazunder S, Datta S, Ray JG, et al. Liquid biopsy: miRNA as a potential biomarker in oral cancer. Cancer Epidemiol 2019;58:137-145. https://doi.org/10.1016/j.canep.2018.12.008

91 Lousada-Fernandez F, Rapado-Gonzalez O, Lopez-Cedrun JL, et al. Liquid biopsy in oral cancer. Int J Mol Sci 2018;19:1704. https://doi. org/10.3390/ijms19061704

92 Arneth B. Update on the types and usage of liquid biopsies in the clinical setting: a systematic review. BMC Cancer 2018;18:527. https:// doi.org/10.1186/s12885-018-4433-3

93 Ribeiro IP, Barbosa de Melo J, Carreira IM. Head and neck cancer: searching for genomic and epigenetic biomarkers in body fluids the state of art. Mol Cytogenet 2019;12:33. https://doi.org/10.1186/ s13039-019-0447-z

94 Hussein AA, Forouzanfar T, Bloemena E, et al. A review of the most promising biomarkers for early diagnosis and prognosis prediction of tongue squamous cell carcinoma. Br J Cancer 2018;119:724-736. https://doi.org/10.1038/s41416-018-0233-4.

95 Economopoulou P, Kotsanti I, Kyrodimos E, et al. Liquid biopsy: an emerging prognostic and predictive tool in head and neck squamous cell carcinoma (HNSCC). Focus on circulating tumour cells (CTCs). Oral Oncol 2017;74:83-89. https://doi.org/10-1016/j.oraloncology.2017.09.012

96 Spector ME, Farlow JL, Haring CT, et al. The potential for liquid biopsies in head and neck cancer. Discover Med 2018;25:251-257.

97 Van Ginkel JH, Huibers MMH, Noorlag R, et al. Liquid biopsy: a future tool for posttreatment surveillance in head and neck cancer? Pathobiology 2017;84:115-120. https://doi.org/10.1159/00045286 